\title{
The Australian Economy in 2016-17: Looking Beyond the Apartment Construction Boom
}

\author{
Tim Robinson, Viet H. Nguyen and Jiao Wang*
}

\begin{abstract}
* Melbourne Institute of Applied Economic and Social Research, The University of Melbourne, Victoria 3010 Australia. Corresponding author: Robinson, email <tim.robinson@unimelb.edu.au>. We thank Guay Lim, Ian McDonald, Sam Tsiaplias and Ross Williams for useful comments. This work was supported by Australian Research Council Discovery Project 160102654.
\end{abstract}

\section{Introduction}

The transition in the sources of growth away from the mining sector continued in 2015-2016. However, this transition was narrowly focused, primarily occurring in residential investment and nonresource exports. Nominal non-mining private business investment grew only moderately.

Inflation was weak during 2015-2016. This reflected low global energy prices, together with subdued domestic final demand and wages growth, despite some improvements in the labour market. This lowinflation environment was a factor contributing to monetary policy being eased once during 2015-16 and again subsequently. The cash rate reached 1.5 per cent, a new low for the inflation-targeting period. Alternatively, fiscal policy settings were little changed.

Looking forward, the concentration of the transition in sources of growth in the housing sector poses risks due to the substantial amount of higher density housing coming on line in several cities. Growth in resource exports, particularly liquefied natural gas (LNG) exports, will support overall output growth, despite a probable continuation of subdued domestic demand (Table 1). Wages and inflation growth appears likely to remain low and consequently monetary policy accommodative. Key international sources of the uncertainty surrounding the outlook include the prospects for Chinese economy and the future conduct of economic policy in the United States.

This article is structured as follows. In Section 2, we discuss both the international economic developments that have impinged on the Australian economy and developments in the terms of trade and the real exchange rate. Section 3 summarises developments in the labour market, inflation, financial markets and the real economy. A focus of Section 3 is on recent developments and the outlook for residential investment. Finally, Section 4 concludes.

\section{International Influences}

The global economy continued to recover in 2016, although at a slower-than-expected rate. The International Monetary Fund (IMF) currently projects global economic growth in 2016 to be 3.1 per cent, down from forecasts of 3.6 per cent made last year (IMF 2016). Growth is expected to pick up moderately in 2017, reaching 3.4 per cent (Figure 1). A sizeable component of this improvement is due to improvements in emerging and developing economies. 


\subsection{The United States}

In the United States, growth in 2016 to date has been lower than expected and this has been a major factor behind the downward revisions to the forecasts for global growth.

The US labour market, however, improved further, with the unemployment rate averaging 4.9 per cent in the first three quarters, its lowest level since 2008 (Figure 2). A caveat is that the participation rate also is at a low level by historical standards. This partially reflects the ageing of the population, such as baby boomers retiring, although it is likely that there also is a cyclical component. ${ }^{1}$ Nevertheless, the improvements in the labour market supported strong consumption growth in the first half of the year. Output growth overall was held down by weak non-residential investment and a sizeable drawdown of inventories, although growth improved in the September quarter.

Despite considerable uncertainty about the future conduct of economic policies in the United States, the Federal Reserve continued the gradual process of returning to normal monetary policy with an increase in the federal funds rate in December.

\subsection{Europe}

Output growth in the Euro area is forecast by the IMF to moderate in both 2016 and 2017. This is despite an expected small pick-up in growth in Germany in 2016 and little change in France and Italy. The IMF attributes low oil prices, expansionary monetary policy and fiscal policy in 2016 as factors which are contributing to growth. Nevertheless, a slowing is expected in Spain, particularly in 2017 (Figure 3).

The ultimate impacts of Brexit (the United Kingdom's decision to leave the European Union) are unclear, as the fate of institutional and trade arrangements between the United Kingdom and the European Union presently are uncertain. The IMF notes that this uncertainty is weighing on growth in the Euro area and forecast a sharp slowdown in the United Kingdom.

The Bank of England in August in response to the Brexit decision lowered the bank rate and introduced a package of additional measures to boost growth and return inflation to target (which presently is very low). ${ }^{2}$ The European Central Bank in December announced that its quantitative easing program will continue until at least the end of 2017, although monthly asset purchases will be less.

\subsection{Japan}

The IMF projects Japan's gross domestic product (GDP) growth to be 0.5 per cent in 2016 and to increase only marginally in 2017. Inflation has continued to be largely absent in Japan in 2016, well below the 2 per cent target set by Bank of Japan (Figure 4). The labour market has improved, supporting growth in unit labour costs (RBA 2016a). A range of new measures, including a negative interest rate policy and targeting long interest rates, was announced by the Bank of Japan throughout 2016. Despite these policies, the improved labour market and a further round of fiscal stimulus, the IMF forecasts the weakness in inflation to continue in 2017 (Figure 4).

\subsection{China}

Growth in China is expected by the IMF to fall into the target range set by the authorities of 6.5-7.0 per cent in 2016. In 2017, growth is expected to slow further, to about 6.2 per cent. The slowdown of 
China's economic growth to its 'new normal', as labelled by President Xi Jinping, continued in 2016. Positive factors, including stable domestic macroeconomic conditions and progressive supply-side structural reforms to reduce excess industrial capacity and shed unviable assets, have boosted the Chinese economy onto a more sustainable, consumption-led growth path. Difficulties, such as the resettlement of employees from over-capacity heavy industries (such as steel and coal), which have been displaced by these reforms, remain. In recent years, China's reduced reliance on import- and resource-intensive investment has adversely impacted commodity-exporting countries, such as Australia, by lowering commodity prices.

China's credit to GDP ratio has risen steadily and quickly since 2008, primarily reflecting lending to the corporate sector (Figure 5; see Kent 2016a). More recently, property prices in Tier 1 cities, such as Beijing, have grown rapidly (Figure 6). Government policy, which encourages purchases of housing with the goal of reducing the level of inventories, and a range of stimulus measures implemented since 2014, such as further urbanisation, have contributed to the latest strengthening of the housing market in major cities (RBA 2016b). Recently, local governments in some regions have introduced measures attempting to cool these markets. This combination of rapid increases in property prices and indebtedness poses potentially serious risks to the Chinese economy.

Chinese growth has been supported by a depreciation in the renminbi. In the second half of 2015, the peg was changed to a basket of currencies instead of the US dollar and a sharp depreciation against the US dollar occurred. In January 2016, the People's Bank of China increased the transparency of the regime and subsequently the renminbi has depreciated further (Figure 7). ${ }^{3}$

\subsection{Terms of Trade and Exchange Rate}

One of the key factors influencing the Australian economy over the past 13 years has been the rise and subsequent fall of the terms of trade (Figure 8). This was driven by the development of China, which drove up demand for Australia's major exports, resources, and the subsequent supply response. In the June quarter 2016, the terms of trade was 34 per cent below its September quarter 2011 peak.

In the second half of 2016, spot prices for the bulk commodities, namely iron ore, thermal and coking coal, increased sharply (Figure 9). The most substantial increases have been for coking coal, which together with iron ore is used in the production of steel. Contributing to these increases have been several factors, such as supply disruptions at Australian mines, measures to curb China's domestic production (see RBA 2016a) and Chinese Government's infrastructure spending and the property market (which have stimulated steel demand). Given the role of supply-side factors, it seems unlikely that such high spot prices will persist in the medium term, although in the near term further increases in the terms of trade are possible.

\section{Australia}

\subsection{Economic Activity}

Many of the trends evident in recent years persisted in 2015-2016. Real GDP growth considerably outstripped that in domestic final demand, primarily reflecting a large contribution to growth by net exports (Figure 10). In the September quarter, output declined, in part due to temporary factors such as wet weather impeding construction. Nevertheless, GDP was 1.8 per cent higher over the year.

One place where the transition has been evident is residential investment. While only a relatively small component of output (approximately 5.5 per cent), it grew by more than 7 per cent over the year 
to the September quarter. Developments in the housing market are considered further in Sub-section 3.5. The transition has also been evident in a pick-up in non-resource exports, such as services (Figure 11).

An important aspect of the mining boom was a substantial increase in investment to boost capacity. In the last few years, following the peak in the terms of trade, mining investment has fallen considerably, which continued in 2015-16. The recent increases in commodity prices are unlikely to spur new mining projects (RBA 2016a). The Australian Bureau of Statistics (ABS) Capital Expenditure Survey (CAPEX) suggests that a further substantial fall will occur in 2016-17 (Figure 12). Thereafter, it seems likely that further falls will be more modest, as a considerable amount of the adjustment has already occurred (the Reserve Bank of Australia (RBA) estimates approximately 80 per cent of the probable total fall; Kent 2016b).

An increase in non-mining investment would help offset the drag on growth from falling mining investment. However, in 2015-16, nominal non-mining investment grew only moderately and in the September quarter was just slightly higher over the year (in trend terms). This is despite measures in the federal budget designed to support small business investment, the further easing in monetary policy and business sentiment, as measured by the National Australia Bank's Monthly Business Survey, being at or above average levels. One factor for the subdued non-mining business investment may be high and sticky hurdle rates being used by firms when assessing investment opportunities (Kent 2014). Other factors that have been raised include heightened uncertainty and risk aversion, the shift towards the services sector and low productivity growth (Kent 2016b).

A positive development for the outlook for non-mining investment is that a leading indicator, trend non-residential building approvals, improved in the second half of 2016. Alternatively, business credit growth has slowed and nominal non-mining investment intentions in the CAPEX survey instead point to little change in 2016-17. Coverage issues, however, limit the usefulness of the CAPEX survey as an indicator for the non-mining sector (see Berkelmans and Spence 2013).

A further contributing factor might be that firms are delaying investment until a sustained upswing in demand is evident. Consumption growth was subdued in 2015-16 and soft in the September quarter, with weak wages growth restraining household income growth. The shift towards part-time employment, which is discussed further below, may have also been a contributing factor. The trend household saving ratio fell in the second half of 2015 and has been broadly unchanged thereafter (Figure 13). It remains well above the particularly low levels reached prior to Global Financial Crisis (GFC). Looking forward, consumption growth is likely to remain below-average, held down by the subdued outlook for wages growth.

Resource exports are likely to remain an important contributing factor to overall output growth in the coming year. The composition of the growth in resource exports, however, is likely to change. The Department of Industry forecast that LNG production and exports will increase by nearly 40 per cent in 2016-17 (Figure 14) (Office of the Chief Economist 2016). As the employment needs of such an increase in production are likely to be modest (see Plumb, Kent and Bishop 2013), this will support labour productivity growth. Australia is poised to become the world's largest producer of LNG (Heath 2016).

The falls in the terms of trade that occurred in 2015-16, stemming from declines in commodity prices, weighed on national income and the federal government budget was also adversely affected. The recent gains in commodity prices alternatively will at least temporarily boost nominal income growth; in the September quarter, it outstripped output growth for the first time since early 2012 (Figure 15).

\subsection{Labour}


The unemployment rate improved over the first 10 months of 2016. It moved down from approximately 6 per cent at the beginning of the year to be around 5.7 per cent in November, a level slightly above estimates of non-accelerating inflation rate of unemployment (NAIRU), although these are inherently imprecise (Figure 16). ${ }^{4}$

Looking across the states, the improvement reflects falls in the unemployment rates in New South Wales and Victoria, which is unsurprising as they have the strongest performing economies, but also South Australia (Figure 17). At the beginning of 2016, South Australia, which is exposed to the manufacturing and mining sectors, had the highest trend unemployment rate in the nation; in November, this had fallen to 6.7 per cent, broadly in line with Western Australia. In contrast, the unemployment rate was the lowest in New South Wales (4.9 per cent). There was little change in the unemployment rate in one of the resource-intensive states, namely Queensland, whereas in Western Australia it has increased and in both it is considerably higher than several years ago.

Underlying the improvement in the unemployment rate, however, were some less encouraging trends. First, the participation rate also decreased, with the improvement that occurred in 2015 now largely unwound (Figure 15). Overall, the employment to population ratio has decreased by around 0.3 percentage point. While the ageing of the population will tend to lower the participation rate, the change this year is too rapid to be the driving factor.

A second less encouraging trend has been a shift in the composition of employment growth towards part-time employment (Figure 18). While a change in preferences by workers to part-time work could be a factor, it should also be noted that such a divergence has occurred during most periods when the economy's domestic demand has slowed considerably. The RBA has suggested weakness in labour demand has been the main contributing factor (RBA 2016a). The shift towards part-time employment has resulted in average hours worked declining and an increase in the proportion of young workers (those aged 15-24 years old) working less hours than they desire (Figure 19).

Focusing on the change in employment from August 2015 to 2016, the largest decrease was in retail trade (38,000 persons) (Table 2). While employment in the retail sector declined in all age groups, except those aged 60 plus, the largest fall was in those who were 15-24 years old (Table 3). The fall was concentrated in full-time positions. Mining sector employment continued to decline and the fall was entirely in full-time positions. On the flip side, employment in professional, scientific and technical services increased the most of any industry, with around two-thirds of the positions fulltime. The shift towards part-time employment, however, was evident in a range of industries. Interestingly, growth in employment was more concentrated in those at either end of the age spectrum, compared to the previous year, at the expense of those aged 25-44 years old (Table 3).

The improvement in the unemployment rate in 2016 has not resulted in stronger wages growth. Growth in the Wage Price Index slowed further, and in year-ended terms, in the September quarter was the slowest on record (Figure 20). The slowing was in both private and public sectors. Analysis by the RBA and ABS of data used to construct the Wage Price Index showed that the frequency and magnitude of changes in wages have declined in recent years (Bishop 2016; Lowe 2016). Nevertheless, real consumer wage growth has remained positive due to the exceptionally low rate of inflation. Another impact of the low wages growth is that it will weigh on taxation receipts. In all, it appears that slack still exists in the labour market and probably to a greater extent than indicated by the unemployment rate.

\subsection{Inflation}

Underlying inflation fell below the RBA's target band of 2-3 per cent in 2015-2016 (Figure 21). Several factors have been attributed by the new RBA Governor, Phil Lowe, as having restrained inflation. These include: (i) the presence of spare capacity; (ii) the low level of commodity prices; (iii) 
decreased pricing power due to globalisation; and (iv) the financial crisis increasing concerns about job security (Lowe 2016).

Unit labour costs, namely wages adjusted for productivity growth, and import prices are two important determinants of inflation. Year-ended growth in unit labour costs has now been negligible for several years due to the weak wages growth coupled with productivity increases (Figure 22). Import price inflation, while volatile, has also been subdued and recently has been negative.

\subsection{Financial Markets}

In 2015-16, Australian financial market conditions continued to be driven by global, rather than domestic, events. In particular, a global environment of low interest rates and volatile share markets set the backdrop for Australian financial conditions.

Long-term bond yields in major developed economies remained at record lows in recent times as global economic activity fell below expectations and investors sought safe havens amid high volatility in share markets (Figure 23). Similarly, yields on long-term Australian Government securities declined further in 2015-16, reaching a record low since the beginning of inflation-targeting. Since around the US election, US yields have increased, reflecting perceived improved growth prospects and possibly concerns of higher future government deficits. Australian yields have also increased and it is unclear to what extent these increases in both countries will persist. The resulting rise in costs of funding for Australian banks has led to some increases in lending rates, independent of monetary policy.

A noticeable common feature amongst international government bond yields is the downward trend since the onset of the GFC. Lowering long-term yields was an aim of some of the unconventional monetary policies adopted during the crisis. Rachel and Smith (2015) attribute the trend decline, in part, to slowing global growth and, in part, to shifts in saving and investment preferences. They also suggest that the persistence of these forces could lead to a new lower global neutral real rate of around 1 per cent in the medium-to-long run.

Figure 23 also shows, aside from the common negative trend, positive spreads have existed between the Australian bonds and the three global benchmarks. These positive spreads result from a combination of differences in: (i) current policy rates; (ii) expected inflation; (iii) expected longer term growth; and (iv) sovereign risk profiles. Given that all are investment-grade, long-term bonds, the current spreads are primarily a reflection of different expected inflation and growth.

Heightened volatility in the Australian share market in 2015-16 reflected the uncertainty surrounding three major global events: (i) the global sell-off in early 2016 amid investors' fear of slowing global growth; (ii) the Brexit decision in late June 2016; and (iii) the US presidential election in early November 2016. A measure of stock market volatility is the VIX. This is constructed as implied volatility from stock index option prices and indicates investors' real-time expected market volatility in the next 30 days.

The Australian VIX is strongly correlated with its US counterpart, the Chicago Board Options Exchange VIX, suggesting that the volatility in Australian share markets in 2016 is almost entirely shaped by global conditions (Figure 24). Nevertheless, the heightened volatility in domestic financial markets may have been a contributing factor to non-mining investment in Australia remaining lacklustre.

\subsection{The Residential Investment Upswing}

The transition in sources of growth has been particularly evident in the housing sector. Residential investment is usually a highly volatile and cyclical component of output (Figure 25). The most recent 
upswing, however, follows a period where overall there was little growth. For example, the level of real residential in 2009 was similar to that in 2003.

The upswing in residential investment has not been uniform across the states and most recently it has been concentrated in the eastern seaboard. The growth in New South Wales follows a protracted period where residential investment was below the levels of the early 2000s, both in per capita terms and as a share of state final demand (SFD) (Figure 26). In contrast, in Victoria, residential investment was at or above those levels and has increased further.

The states most impacted by the downturn in the mining sector, namely Western Australia and Queensland, have shown different trends. Prior to the GFC in both states, residential investment was at a particularly high level in per capita terms (Figure 26). While it presently is lower, it remains elevated. Its increase as a share of SFD since around 2013 is, in part, due to falls in mining investment. Recently, residential investment has been growing strongly in Queensland, whereas it has been falling in Western Australia.

The upswing in residential investment has been primarily concentrated in buildings other than detached dwellings (houses), such as apartments (Figure 27). The magnitude of this increase in the construction of dwellings other than houses is substantial (Table 4). An example is that commencement of construction of these buildings in Victoria in 2015 was around 8 per cent of the occupied stock in 2011.

This expansion is not yet over. Figure 28 shows that smoothed building approvals for private dwellings other than houses (including both alteration and additions to existing buildings and new construction) per million persons at the end of 2015, while having peaked, was at a high level in all of the eastern seaboard states.

A fundamental factor that drives residential investment is population growth. Since the second half of 2012, Australia's population growth has generally slowed. This slowing has been particularly pronounced in the mining states, especially Western Australia. Victoria presently has the strongest population growth in the country (Figure 29$)^{5}$

Another fundamental factor contributing to the upswing has been the historically low level of interest rates. Additionally, a preference shift towards smaller dwellings or closer proximity to major commercial districts could also be contributing. One aspect of this may be baby boomers trading down to apartments.

Investment by foreign nationals (particularly Chinese) in higher density housing has also been widely discussed in the popular press as adding to demand. Unfortunately, it is difficult to quantify its importance.

Apartment prices have shown resilience in the face of this rapid increase of supply and prospects of its continuation in the near term (Figure 30). Growth over the year to the September quarter remained positive in the three cities with the largest growth in supply: Sydney, Brisbane and Melbourne. Prices growth, however, has slowed, particularly in Sydney, where both house and apartment prices previously were growing particularly strongly (Figure 30). ${ }^{6}$ In Perth and Darwin house and apartment prices have fallen over the year.

In late 2014, the prudential regulator, the Australian Prudential Regulation Authority, introduced new policies in an attempt to enhance the quality of residential lending. This included, amongst other measures, a 10 per cent ceiling on investor credit growth. Subsequently, investor credit growth has slowed markedly (Figure 31). The RBA (2016c) showed that banks' exposure to mortgage losses is likely to be small unless the price falls are large. ${ }^{7}$ 
The broader macroeconomic impacts of a fall in apartment prices include that it would dissuade further residential investment, which might be amplified by a tightening in lending standards by financial institutions. The adverse impact on household wealth could dampen consumption growth.

The RBA has also repeatedly expressed concerns over the commercial office property market (see, for example, RBA 2016c). This was a source of financial instability in the late 1980s. In recent years, while differences exist across cities, in aggregate, prices have risen strongly despite little growth in rents.

\section{Concluding Remarks}

The Australian economy in 2015-16 continued the transition in sources of growth that has now been underway for several years. Unfortunately, this transition has remained narrowly based. It has primarily been in residential investment and some non-resource exports, such as services. Nominal non-mining investment grew only moderately in 2015-16. While the drag on output growth from falling mining investment may well lessen in the coming year, ultimately what is needed is for the pace of non-mining investment to increase. It is difficult to know when this will occur-it could require an accompanying sustained pick-up in consumption growth to underpin it. In an environment of low wages growth, this seems unlikely.

The recent strength in commodity prices will support fiscal revenues, although it is highly uncertain to what extent these price gains will persist. On the flip side, low nominal wages growth will be a drag on revenues. While the need to undertake fiscal consolidation remains as the federal government is running a structural deficit, the fiscal position is such that further measures could be undertaken in the near term to promote non-mining business investment and thereby broaden the sources of growth (Figures 32 and 33).

The main risk to the outlook remains the Chinese economy. Concerns exist over the rapid increases in house prices in major Chinese cities and the stability of its banking system. Another uncertainty is which of President-elect Trump's pre-election promises translate into policies. Some, such as a boost in infrastructure spending, potentially could support commodity prices, benefiting Australia, whereas a shift towards protectionist policies could have adverse impacts.

Overall, it seems likely that, in the near term, domestic demand growth will continue to be modest and, at best, improve only gradually, with growth in exports supporting overall output growth.

December 2016

\section{References}

Aaronson, S., Cajner, T., Fallick, B., Galbis-Reig, F., Smith, C. and Wascher, W. 2014, 'Labour force participation: Recent developments and future prospects', Brookings Papers on Economic Activity, Fall, pp. 197-271.

Ballantyne, A., De Voss, D. and Jacobs, D. 2014, 'Unemployment and spare capacity in the labour market', Reserve Bank of Australia Bulletin, September, pp. 7-14. 
Berkelmans, L. and Spence, G. 2013, 'Realisation ratios in the Capital Expenditure Survey', Reserve Bank of Australia Bulletin, December, pp. 1-6.

Bishop, J. 2016, 'The size and frequency of wage changes', in Wage Price Index, Australia, September 2016, Cat. no. 6345.0, ABS, Canberra.

Gruen, D., Pagan, A. R. and Thompson, C. 1999, 'The Phillips Curve in Australia', Journal of Monetary Economics, vol. 44, p. 223-58.

Heath, A. 2016, 'The future of energy demand and implications for Australia', address to Committee for Economic Development of Australia's NSW Energy Series: Future Energy Projects, Sydney, 21 June, viewed December 2016, <http://www.rba.gov.au/speeches/2016/sp-so2016-06-21.html>.

International Monetary Fund 2016, World Economic Outlook, October, IMF, Washington, DC.

Kent, C. 2014, ‘Non-mining business investment - Where to from here?', address to Bloomberg Economic Summit, Sydney, 16 September, viewed December 2016, $<$ http://www.rba.gov.au/speeches/2014/spag-160914.html>.

Kent, C. 2016a, 'The economic transition in China', address to Economic Society of Australia (Qld) Business Lunch, Brisbane, 16 June, viewed December 2016, <http://www.rba.gov.au/speeches/2016/sp-ag-2016-06-16.html>.

Kent, C. 2016b, ‘Australia’s economic transition - State by state', address to Australian Business Economists Conference Dinner, Sydney, 22 November, viewed December 2016, $<$ http://www.rba.gov.au/speeches/2016/sp-ag-2016-11-22.html>.

Lim, G., Dixon, R. and Tsiaplias, S. 2009, 'Phillips Curve and the equilibrium unemployment rate', Economic Record, vol. 85, pp. 371-82.

Lowe, P. 2016, 'Inflation and Monetary Policy', address to Citi's $8^{\text {th }}$ annual Australian and New Zealand Investment Conference, Sydney, 18 October, viewed December 2016, $<$ http://www.rba.gov.au/speeches/2016/sp-gov-2016-10-18.html>.

Office of the Chief Economist 2016, Resources and Energy Quarterly, September, Department of Industry, Canberra.

Plumb, M., Kent, C. and Bishop, J. 2013, 'Implications for the Australian economy of strong growth in Asia’, Reserve Bank of Australia Research Discussion Paper no. 2013-03, Sydney.

Rachel, L. and Smith, T. D. 2015, 'Secular drivers of the global real interest rate', Bank of England Staff Working Paper no. 571, London.

Reserve Bank of Australia 2016a, Statement on Monetary Policy, November, Sydney.

Reserve Bank of Australia 2016b, Statement on Monetary Policy, August, Sydney.

Reserve Bank of Australia 2016c, Financial Stability Reviews, October, Sydney.

Stapledon, N. 2016, 'The inexorable rise in house prices in Australia since 1970: Unique or not?', Australian Economic Review, vol. 49, pp. 317-27.

Treasury 2016, Final Budget Outcome 2015-16, viewed December 2016, $<$ http://www.budget.gov.au/2015-16/content/fbo/html/index.htm>. 


\begin{tabular}{|c|c|c|c|c|}
\hline \multirow[b]{2}{*}{ Variable } & \multirow[b]{2}{*}{$2016^{b}$} & \multicolumn{3}{|c|}{$2017^{a}$} \\
\hline & & $M I^{c}$ & Low $^{d}$ & $\mathrm{High}^{d}$ \\
\hline GDP & 2.3 & 2.2 & 2.4 & 3.2 \\
\hline Consumption & 2.7 & 2.5 & 2.0 & 3.3 \\
\hline Domestic final demand & 1.4 & 1.1 & - & - \\
\hline Unemployment rate & 5.7 & 5.7 & 5.1 & 5.9 \\
\hline Employment growth & 1.6 & 1.1 & - & - \\
\hline Wage Cost Index & 2.0 & 1.9 & 2.1 & 3.1 \\
\hline Headline inflation & 1.2 & 1.8 & 1.5 & 2.7 \\
\hline Underlying inflation & 1.7 & 1.7 & - & - \\
\hline 90 day bill rate ${ }^{\mathrm{f}}$ & 1.7 & 1.8 & 1.2 & 2.1 \\
\hline
\end{tabular}

Notes: (a) Forecasts.

(b) Estimates.

(c) MI denotes Melbourne Institute.

(d) Based on published forecasts in Consensus, November 2016.

(e) GDP denotes gross domestic product.

(f) As at end November 2017.

Sources: Melbourne Institute and Consensus: A Digest of

Economic Forecasts. 
Table 2 Employment by Industries ('000): Full-Time (FT) and Part-Time (PT)

\begin{tabular}{|c|c|c|c|c|c|c|c|c|c|}
\hline \multirow[b]{2}{*}{ Industry } & \multicolumn{3}{|c|}{$\begin{array}{l}\text { Change between August } \\
2014 \text { and August } 2015\end{array}$} & \multicolumn{3}{|c|}{$\begin{array}{l}\text { Change between August } \\
2015 \text { and August } 2016\end{array}$} & \multicolumn{3}{|c|}{ Ratio of FT to PT } \\
\hline & $F T$ & $P T$ & Total & $F T$ & $P T$ & Total & $\begin{array}{l}\text { August } \\
2014\end{array}$ & $\begin{array}{c}\text { August } \\
2015\end{array}$ & $\begin{array}{c}\text { August } \\
2016\end{array}$ \\
\hline Agriculture, forestry and fishing & -14 & -7 & -20 & -3 & -1 & -4 & 2.6 & 2.6 & 2.6 \\
\hline Mining & 12 & -2 & 11 & -24 & 1 & -23 & 27.9 & 36.7 & 27.5 \\
\hline Manufacturing & -28 & -17 & -45 & 1 & -2 & -1 & 4.8 & 5.2 & 5.3 \\
\hline Electricity, gas, water and waste services & 8 & 2 & 10 & -18 & -2 & -20 & 13.5 & 12.2 & 13.5 \\
\hline Construction & 10 & -13 & -3 & 21 & 2 & 23 & 5.1 & 5.6 & 5.6 \\
\hline Wholesale trade & -26 & 0 & -26 & -7 & 7 & 0 & 4.9 & 4.6 & 4.0 \\
\hline Retail trade & 1 & -15 & -14 & -31 & -8 & -38 & 1.0 & 1.0 & 1.0 \\
\hline Accommodation and food services & -6 & 25 & 18 & 18 & 31 & 48 & 0.8 & 0.7 & 0.7 \\
\hline Transport, postal and warehousing & 12 & 4 & 16 & -9 & 7 & -2 & 3.9 & 3.9 & 3.6 \\
\hline $\begin{array}{l}\text { Information media and } \\
\text { telecommunications }\end{array}$ & -4 & 1 & -3 & -4 & -1 & -4 & 4.3 & 4.1 & 4.1 \\
\hline Financial and insurance services & -8 & -3 & -11 & 10 & 5 & 15 & 4.7 & 4.8 & 4.6 \\
\hline Rental, hiring and real estate services & -11 & -2 & -13 & -5 & 7 & 3 & 3.6 & 3.5 & 2.9 \\
\hline $\begin{array}{l}\text { Professional, scientific and technical } \\
\text { services }\end{array}$ & 18 & 11 & 29 & 50 & 26 & 76 & 3.6 & 3.5 & 3.3 \\
\hline Administrative and support services & 25 & 19 & 44 & 10 & 23 & 33 & 1.5 & 1.5 & 1.3 \\
\hline Public administration and safety & 10 & 0 & 9 & 26 & 8 & 34 & 4.3 & 4.4 & 4.3 \\
\hline Education and training & 24 & -6 & 18 & 12 & 1 & 13 & 1.4 & 1.5 & 1.5 \\
\hline Health care and social assistance & 39 & 65 & 104 & -7 & 14 & 6 & 1.3 & 1.2 & 1.2 \\
\hline Arts and recreation services & 23 & -17 & 7 & 2 & 10 & 12 & 0.9 & 1.3 & 1.2 \\
\hline Other services & -1 & -8 & -9 & -6 & 18 & 12 & 2.3 & 2.4 & 2.1 \\
\hline Total (industries) & 85 & 36 & 121 & 35 & 148 & 183 & 2.2 & 2.2 & 2.1 \\
\hline
\end{tabular}

Source: Australian Bureau of Statistics, Labour Force, Australia, Detailed, Quarterly, August 2016, Table EQ05.

Table 3 Job creation by Industries and Age Groups ('000)

\begin{tabular}{|c|c|c|c|c|c|c|c|c|}
\hline & \multicolumn{4}{|c|}{$\begin{array}{l}\text { Change between August } 2014 \text { and August } \\
2015\end{array}$} & \multicolumn{4}{|c|}{$\begin{array}{l}\text { Change between August } 2015 \text { and August } \\
2016\end{array}$} \\
\hline & \multicolumn{8}{|c|}{ Age group (years) } \\
\hline Industry & $15-24$ & $25-44$ & $45-59$ & $60+$ & $15-24$ & $25-44$ & $45-59$ & $60+$ \\
\hline Agriculture, forestry and fishing & -3.7 & -0.7 & -12.8 & -3.0 & 4.3 & -1.9 & -1.0 & -5.0 \\
\hline Mining & -2.2 & -2.5 & 12.9 & 2.4 & 0.9 & -13.1 & -8.7 & -1.6 \\
\hline Manufacturing & -3.5 & -39.4 & -4.3 & 2.0 & -3.2 & 29.7 & -30.5 & 2.7 \\
\hline Electricity, gas, water and waste services & -3.2 & 7.9 & 1.5 & 3.8 & 1.1 & -11.2 & -5.2 & -4.6 \\
\hline Construction & -1.7 & 17.8 & -13 & -6.3 & -4.2 & 23.9 & 8.4 & -5.2 \\
\hline Wholesale trade & 15.6 & -14.4 & -16.9 & -10.5 & -9.0 & -0.7 & 5.9 & 3.5 \\
\hline Retail trade & -0.3 & -16.7 & 16.7 & -13.7 & -19.0 & -14.3 & -12.9 & 8.2 \\
\hline Accommodation and food services & 2.2 & 35.1 & -19 & 0.2 & 29.6 & 2.0 & 17.0 & -0.5 \\
\hline Transport, postal and warehousing & -5.9 & -11.0 & 25.8 & 6.9 & -4.5 & -6.0 & 2.0 & 6.4 \\
\hline $\begin{array}{l}\text { Information media and } \\
\text { telecommunications }\end{array}$ & -1.1 & 7.0 & -7.0 & -1.6 & 6.1 & -13.5 & 0.8 & 2.2 \\
\hline Financial and insurance services & -2.5 & -3.2 & 5.8 & -10.5 & -4.9 & 22.1 & -8.2 & 5.8 \\
\hline Rental, hiring and real estate services & -9.7 & -3.4 & 2.5 & -2.6 & 9.0 & -6.4 & -3.5 & 3.5 \\
\hline $\begin{array}{l}\text { Professional, scientific and technical } \\
\text { services }\end{array}$ & 0.3 & 10.9 & 0.7 & 17.0 & 13.1 & 46.1 & -1.0 & 17.9 \\
\hline Administrative and support services & 6.3 & 19.0 & 14.6 & 3.9 & 4.6 & 21.0 & 5.5 & 1.4 \\
\hline Public administration and safety & 9.3 & 6.3 & -5.7 & -0.6 & -3.7 & 7.3 & 15.5 & 14.8 \\
\hline Education and training & 1.4 & 16.8 & -3.5 & 3.0 & 0.6 & -2.4 & 19.4 & -4.5 \\
\hline Health care and social assistance & 14.1 & 19.8 & 46.8 & 23.1 & -8.4 & 9.4 & 12.2 & -6.8 \\
\hline Arts and recreation services & -11.6 & 14.2 & -1.1 & 5.0 & 9.0 & -8.7 & 8.6 & 3.4 \\
\hline Other services & -0.4 & 14.9 & -13.5 & -10.2 & -2.9 & -3.8 & 10.5 & 8.3 \\
\hline Total (industries) & 3.4 & 78.4 & 30.5 & 8.3 & 18.5 & 79.5 & 34.8 & 49.9 \\
\hline Total & \multicolumn{4}{|c|}{120.6} & \multicolumn{4}{|c|}{182.7} \\
\hline
\end{tabular}

Source: Australian Bureau of Statistics, Labour Force, Australia, Detailed, Quarterly, August 2016, Table EQ12. 
Table 4 Dwellings Other than Houses

Commencements in 2015 as a Proportion of Stock

\begin{tabular}{lc}
\hline & $2015 \%$ of 2011 occupied \\
State & stock \\
\hline New South Wales & 4.7 \\
Victoria & 8.0 \\
Queensland & 7.7 \\
South Australia & 2.2 \\
Western Australia & 5.0 \\
\hline
\end{tabular}

Note: Occupied stock includes semi-detached housing, flats, units and apartments occupied as at the 2011 Census.

Sources: Authors' calculations; Australian Bureau of Statistics.

Figure 1 Global Growth

(\%)

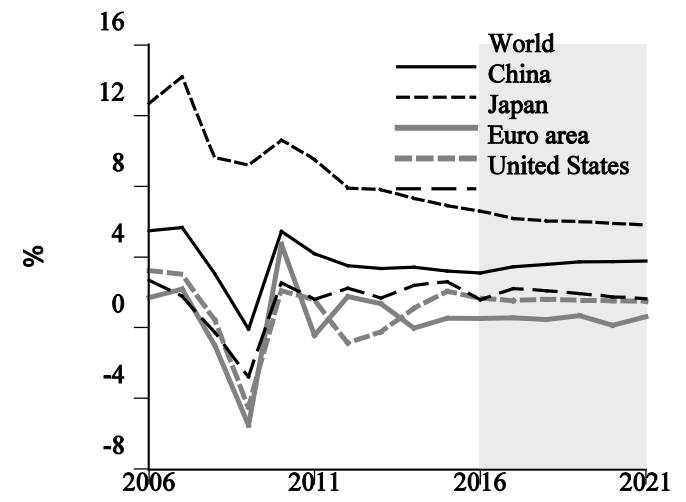

Note: Grey area is IMF forecasts.

Source: IMF (2016).

Figure 2 US Unemployment Rate and Participation Rate, Monthly

(\%)

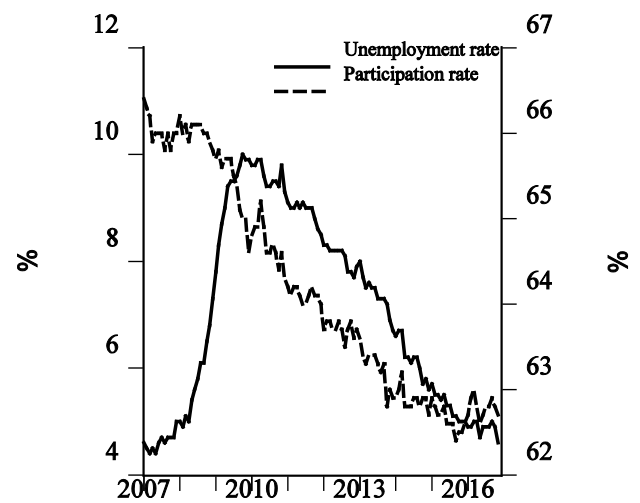

Source: Federal Reserve Bank of St Louis.
Figure 3 Growth in Europe

(\%)

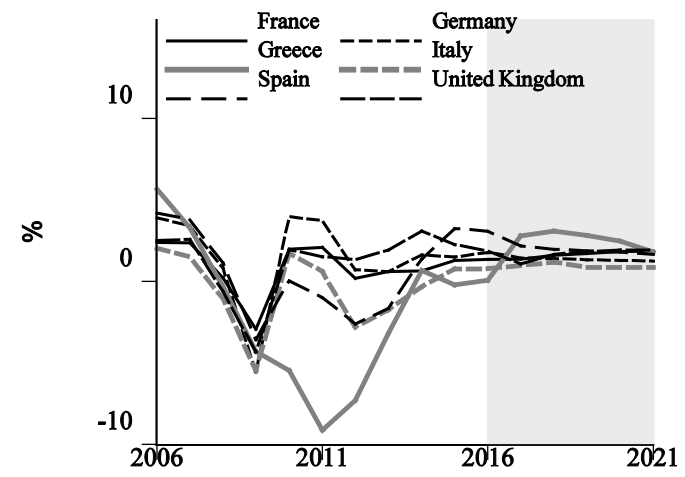

Note: Grey area is IMF forecasts.

Source: IMF (2016).

Figure 4 (Consumer Price Index) Inflation in Japan (\%)

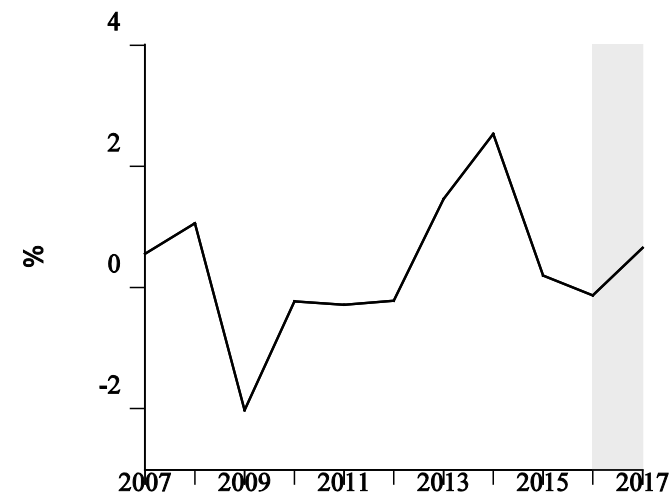

Note: Grey area is IMF forecasts.

Source: IMF (2016).

Figure 5 China's Credit

(\% of gross domestic product)

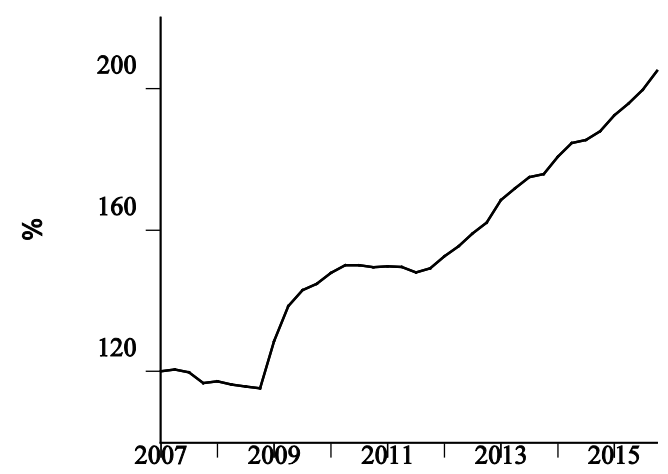


Figure 6 China's Residential Property Price for Beijing (index, $2015=100$ )

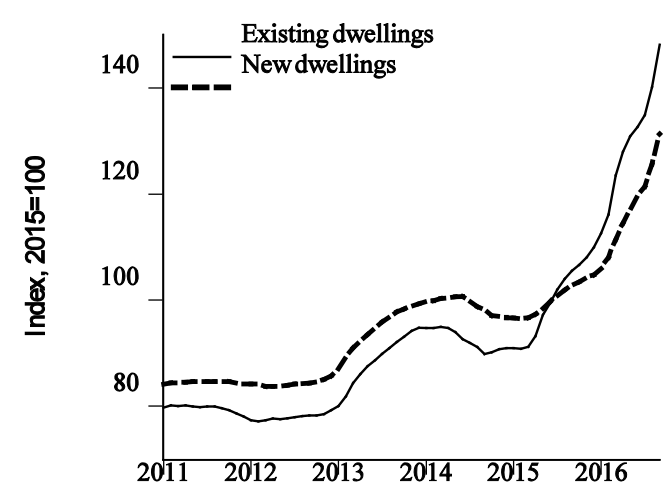

Source: National Bureau of Statistics of China.

Figure 7 The Renminbi per US Dollar, Period Average

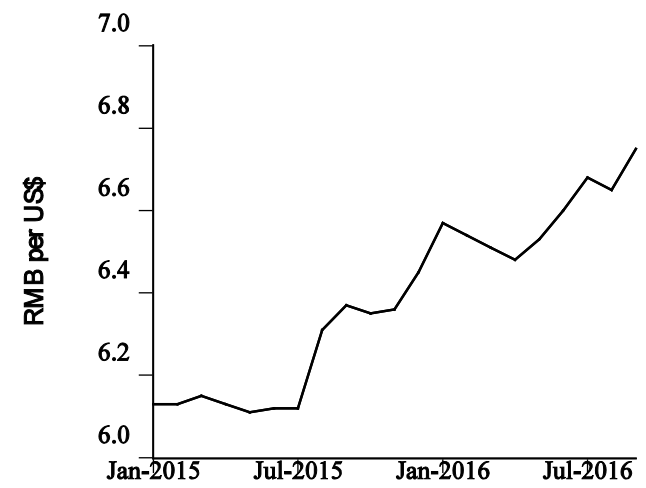

Source: IMF, International Financial Statistics.

Figure 8 Australia's Terms of Trade and Real Exchange Rate, Quarterly

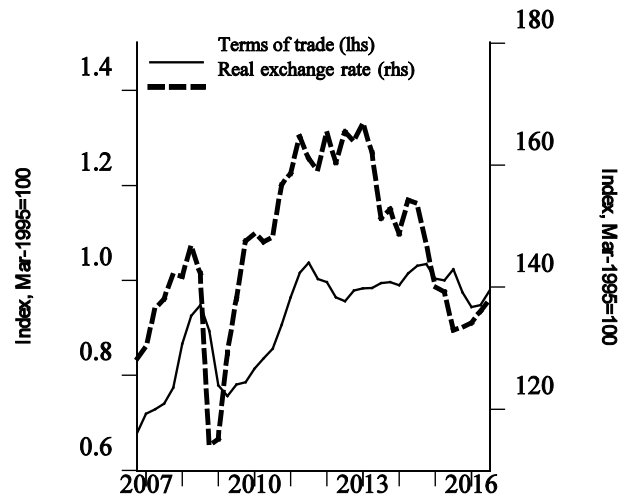

Sources: Australian Bureau of Statistics; Reserve Bank of Australia.
Figure 9 Reserve Bank of Australia Index of Spot Bulk Commodity Prices (SDR, 2014-15 = 100)

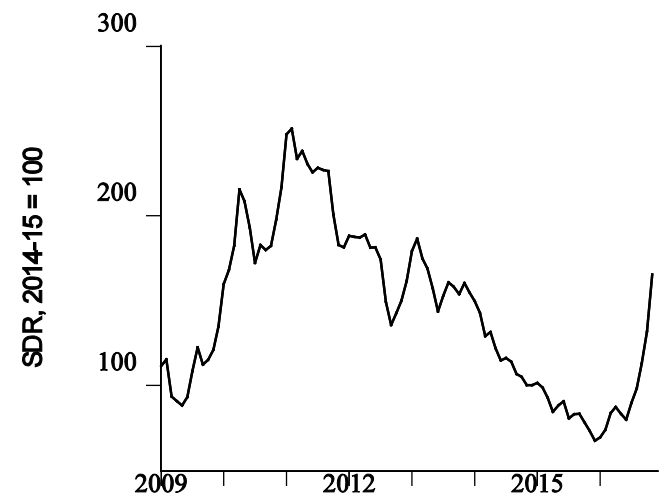

Note: SDR denotes special drawing rights.

Source: RBA.

Figure 10 Real Gross Domestic Product and Domestic Final Demand Growth (year-ended)

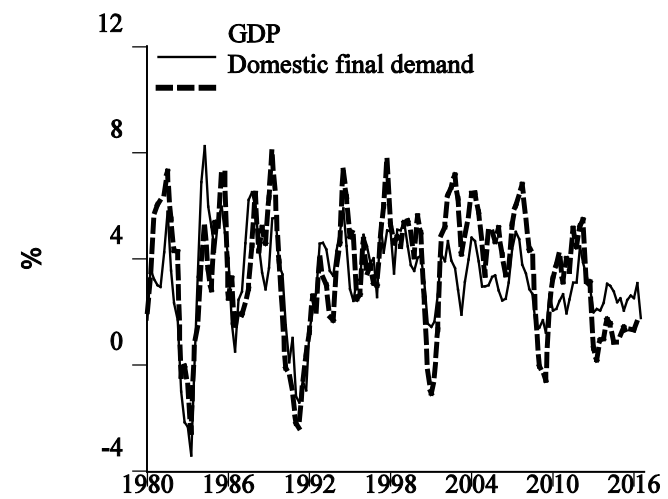

Source: Australian Bureau of Statistics.

Figure 11 Real Exports Growth (three-quarter centred moving average, year-ended)

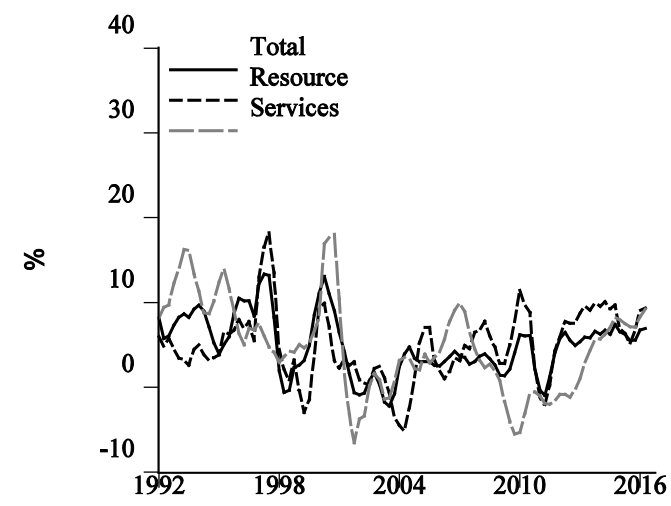


Figure 12 Nominal Business Investment (\$billion)

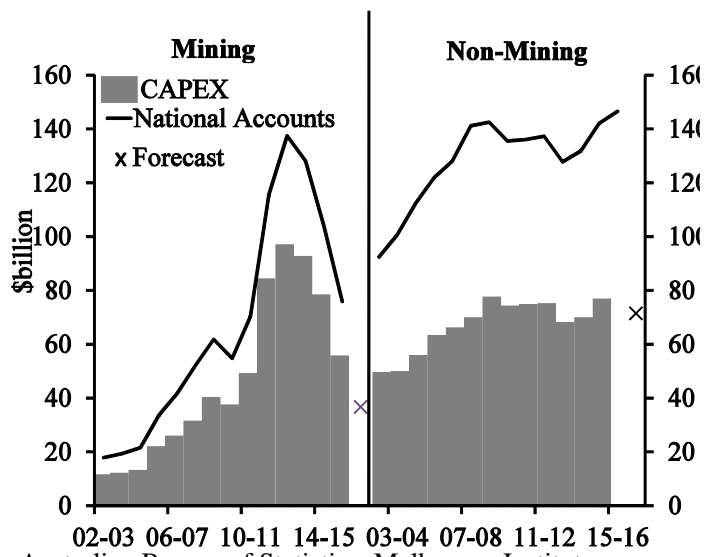

Sources: Australian Bureau of Statistics; Melbourne Institute

Figure 13 Trend Household Saving Ratio

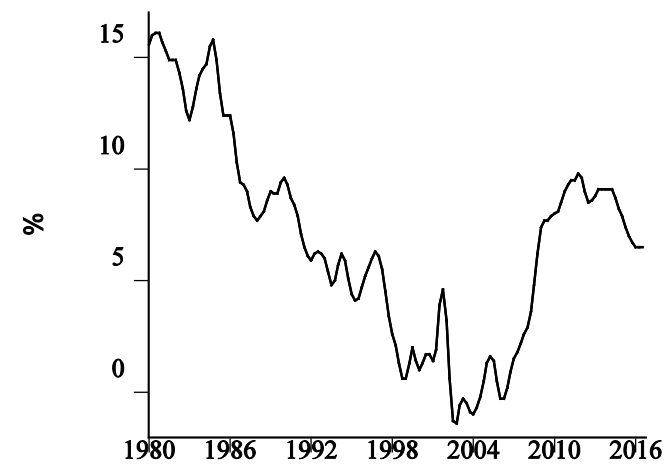

Source: Australian Bureau of Statistics.

Figure 14 Iron Ore and Liquefied Natural Gas (LNG) Exports (Mt)

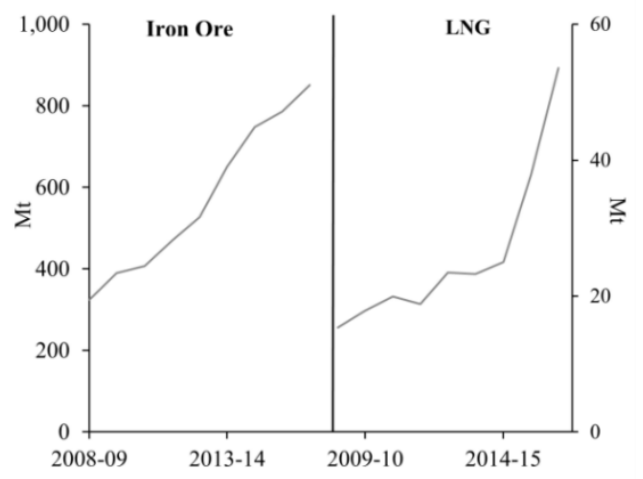

Notes: Includes forecasts for 2016-17.

Source: Office of the Chief Economist (2016).

Figure 15 Difference between Real Gross National Income and Output Growth

(year-ended, percentage point)

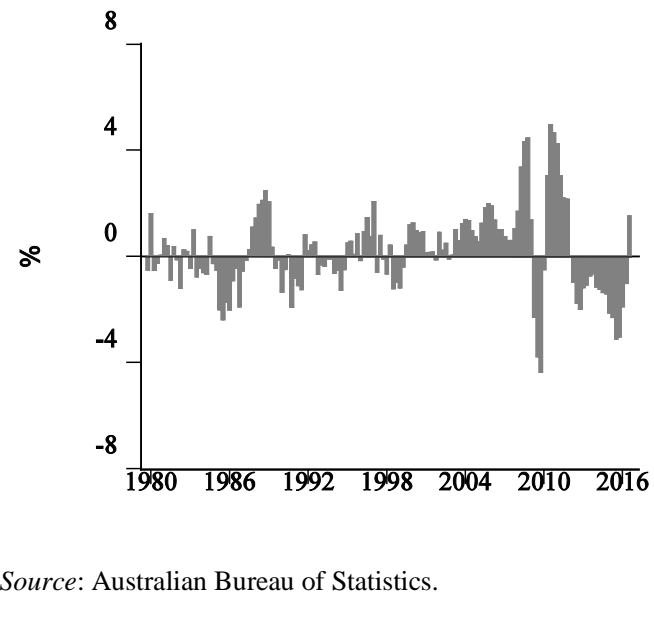

Figure 16 Unemployment and Participation Rate (trend, \%)

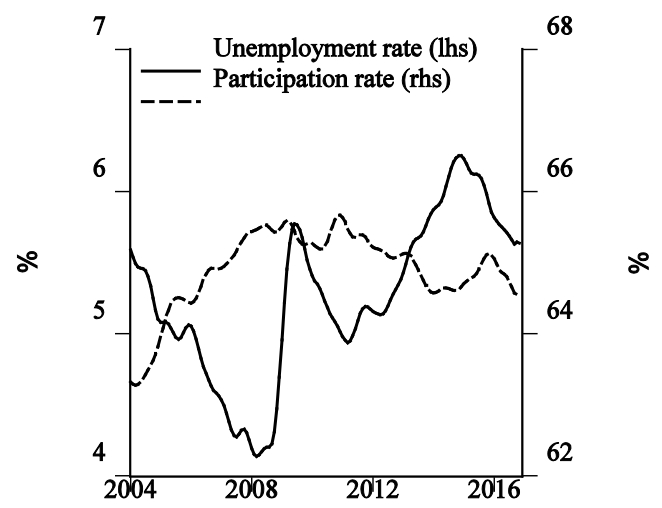

Source: Australian Bureau of Statistics.

Figure 17 State Unemployment Rates (trend, \%)

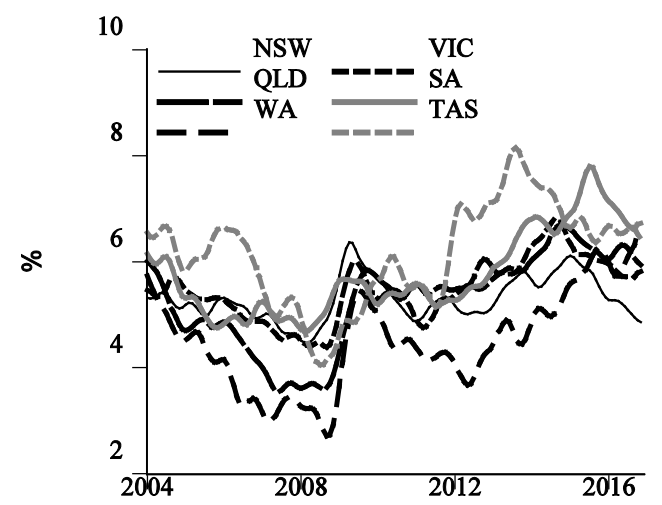

Source: Australian Bureau of Statistics.

Figure 18 Employment Growth (trend, \%) 


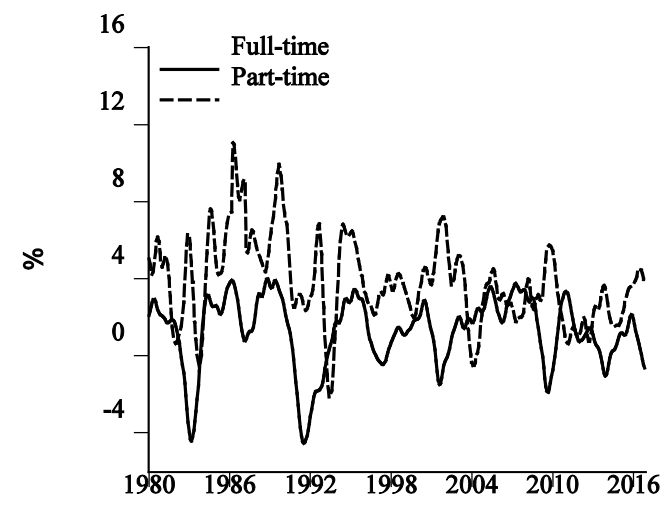

Source: Australian Bureau of Statistics.

Figure 19 Labour Underutilisation (trend, \%)

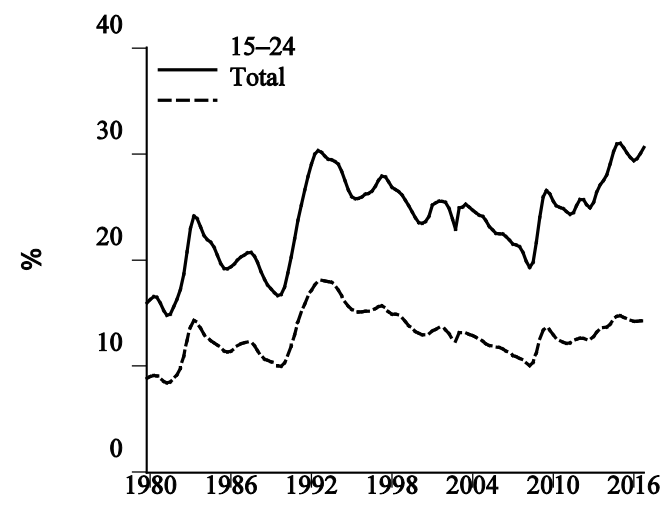

Source: Australian Bureau of Statistics.

Figure 20 Wage Price Index Growth (year-ended, \%)

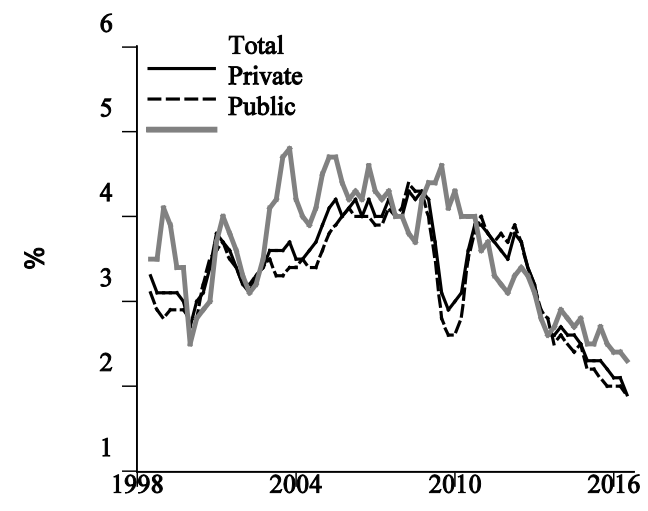

Source: Australian Bureau of Statistics.

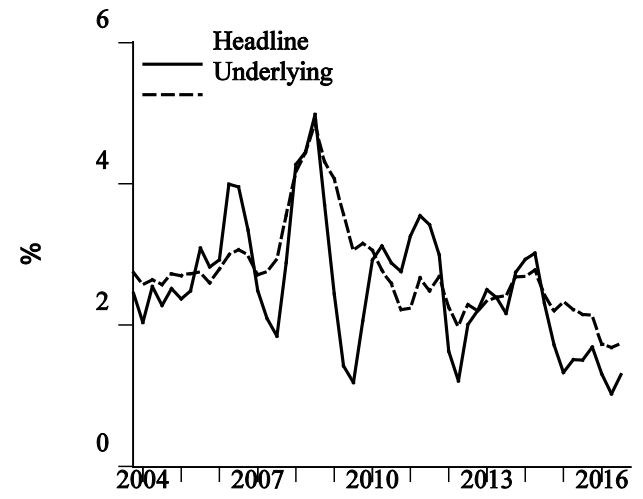

Source: Australian Bureau of Statistics.

Figure 22 Inflation Determinants

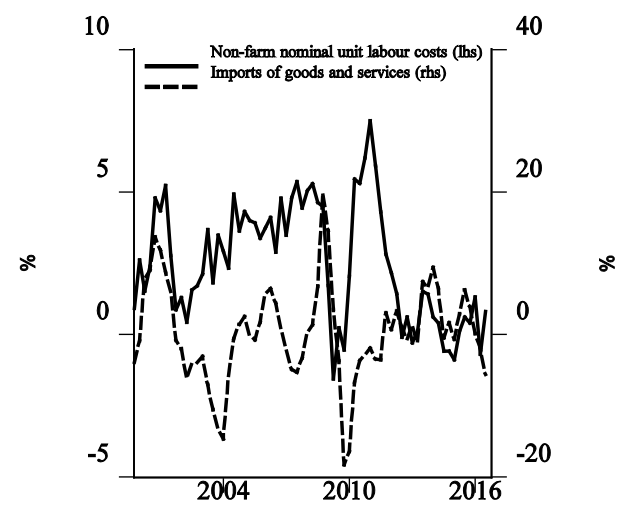

Source: Australian Bureau of Statistics.

Figure 23 Australian Bond and Key Benchmark Bonds (10 years)

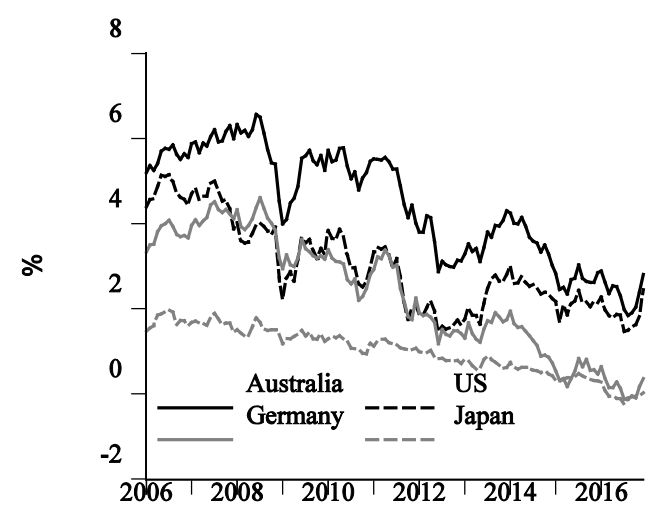

Source: Datastream. 
Figure 24 Volatility Indices

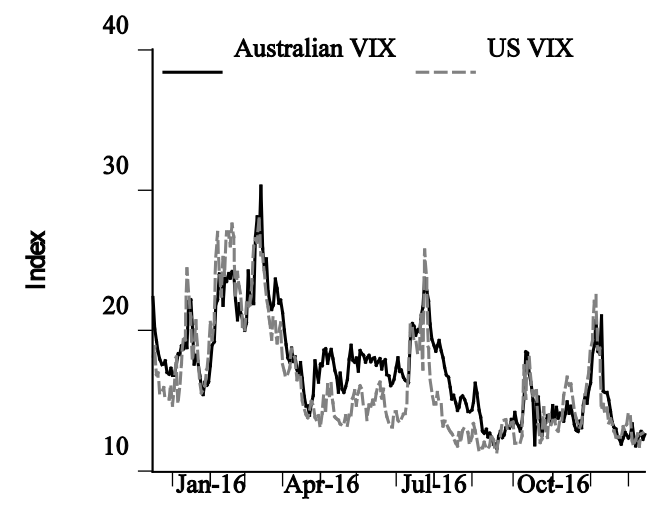

Source: Datastream and St Louis FRED.

Figure 25 Real Residential Investment Growth (year-ended)

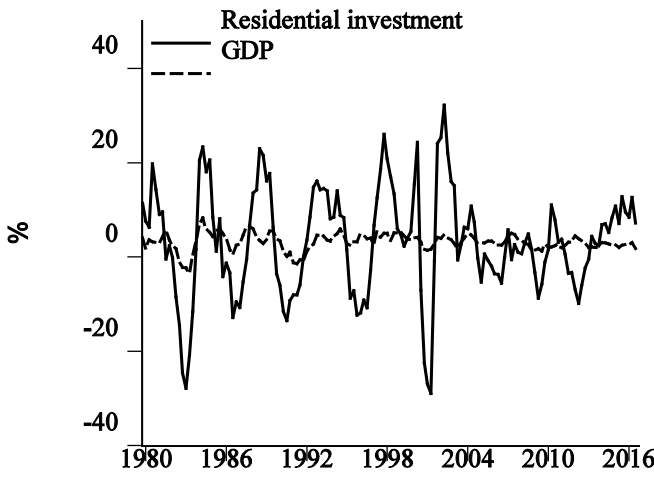

Note: GDP denotes gross domestic product. Source: Australian Bureau of Statistics.
Figure 26 Real Residential Investment for Selected States

(trend)
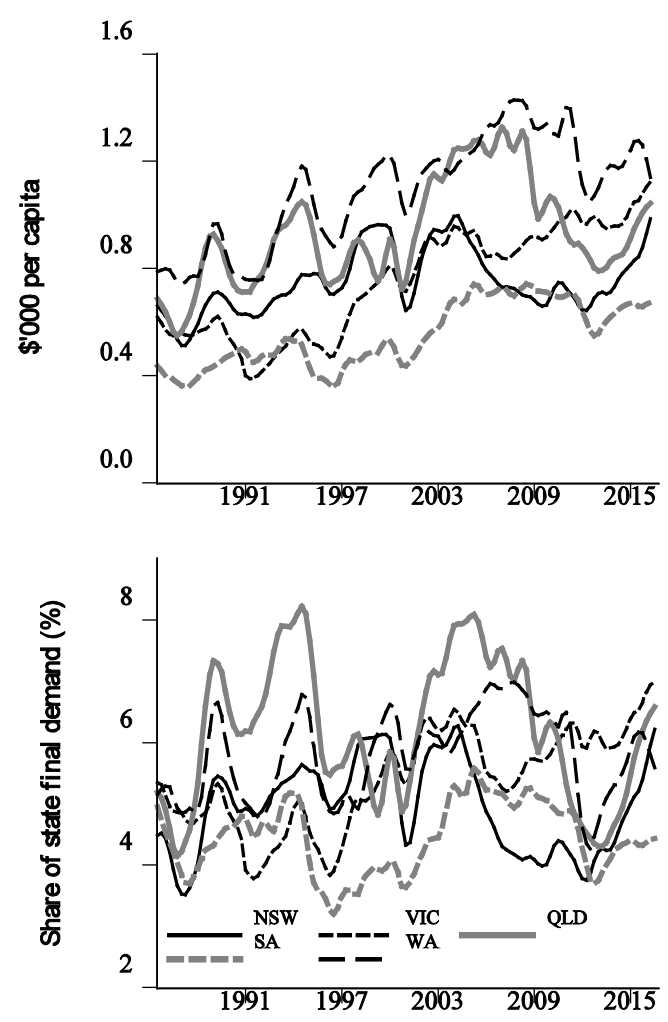

Source: Australian Bureau of Statistics.

Figure 27 Value of Residential Work Commenced (chain volume, trend)

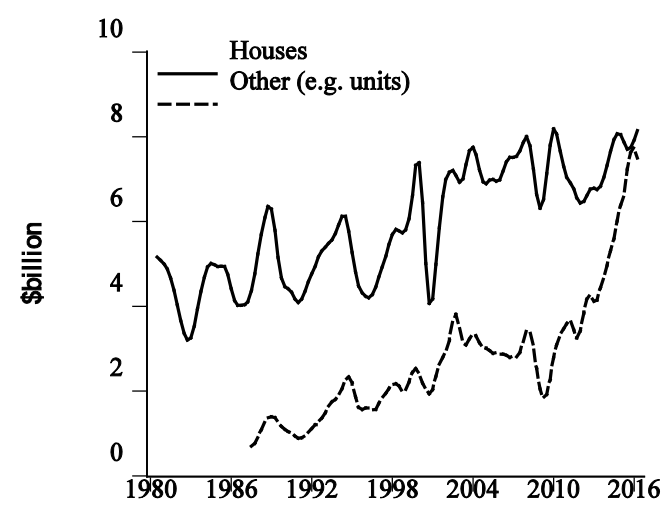

Source: Australian Bureau of Statistics. 
Figure 28 Approvals for Private Dwellings Other than Housing per Million Persons

(seasonally adjusted, three-quarter centred moving average)

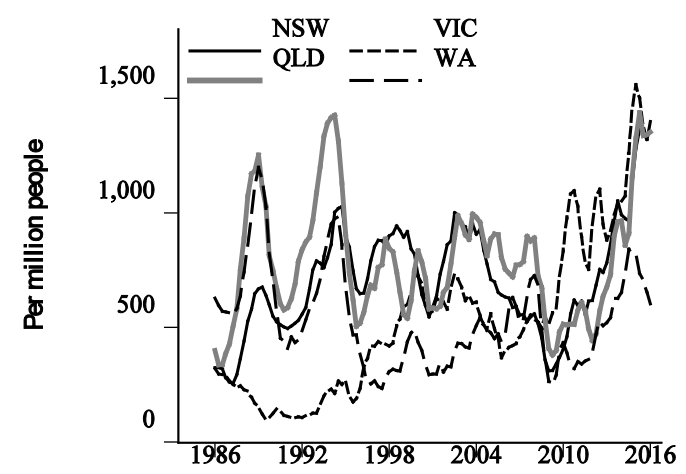

Note: Seasonally adjusted by the Melbourne Institute. Source: Australian Bureau of Statistics.

Figure 29 Population Growth (year-ended)

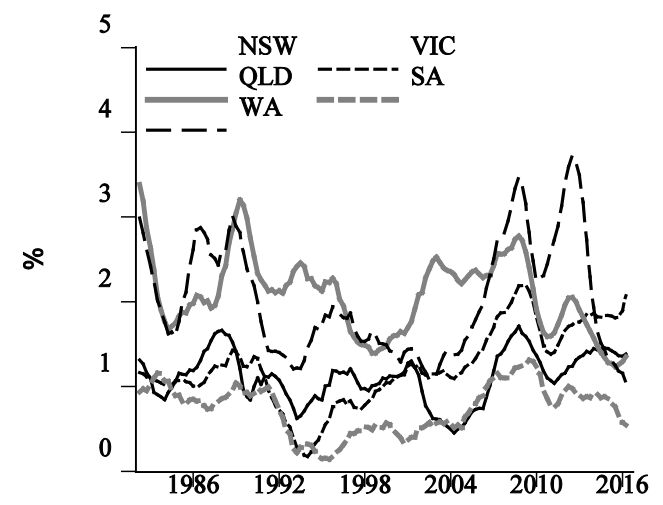

Source: Australian Bureau of Statistics.
Figure 30 Growth in Nominal Dwelling Prices for Selected States

(year-ended)
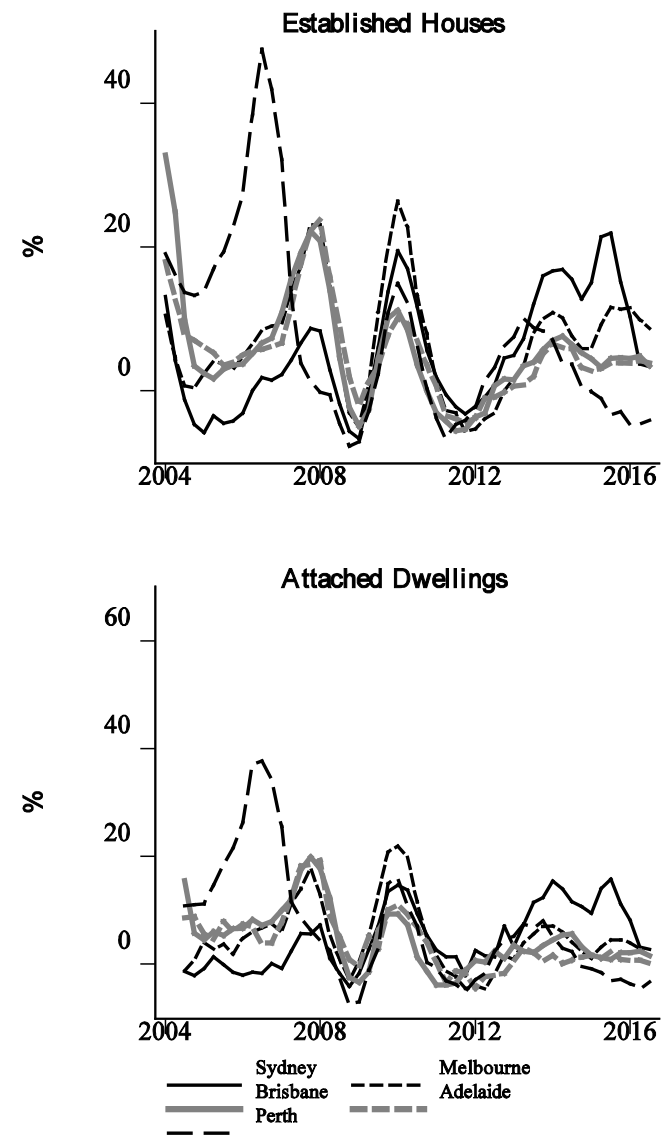

Source: Australian Bureau of Statistics.

Figure 31 Growth in Housing Credit (year-ended)

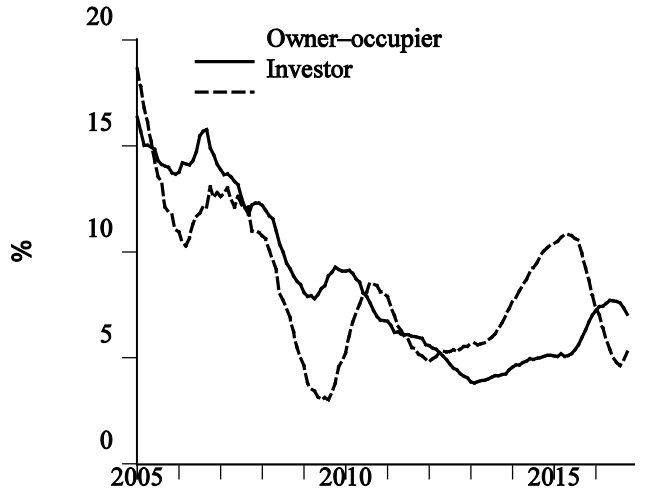


Figure 32 Australian Government Finances

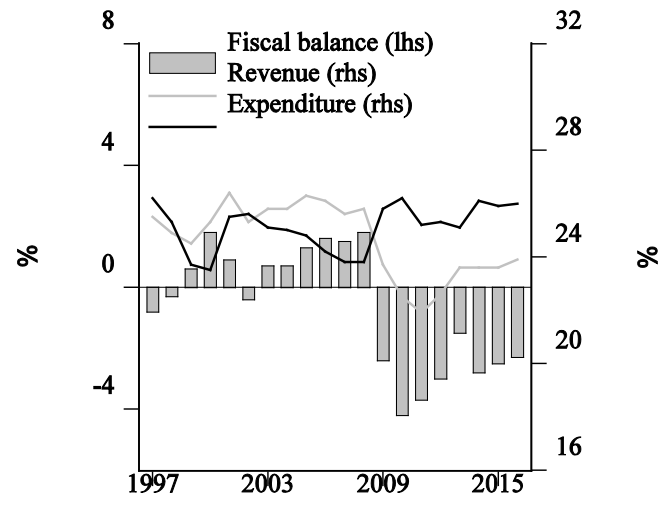

Source: Treasury (2016).
Figure 33 Australian Government Net Debt

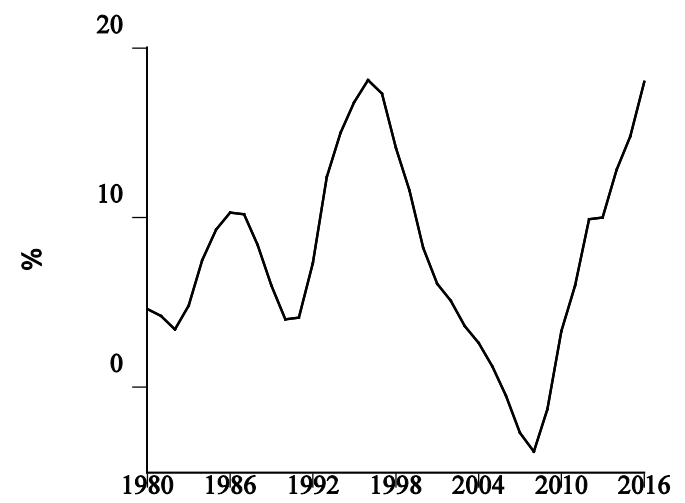

Source: Treasury (2016).

\section{Endnotes}

1. See, for example, Aaronson et al. (2014) or

$<$ https://www.whitehouse.gov/sites/default/files/docs/20150806_labor_force_participation_retirement_research_consortium. pdf $>$.

2. See <http://www.bankofengland.co.uk/publications/Pages/news/2016/008.aspx>.

3. On 3 January 2016, the People's Bank of China announced that the central parity rate of the renminbi against the US dollar would be based on a weighted average of prices offered by market-makers before the opening of the interbank market each business day and the renminbi would be allowed to rise or fall by 2 per cent from the central parity rate each trading day in China's spot foreign exchange market.

4. For example, Ballantyne, De Voss and Jacobs (2014) update the model of Gruen, Pagan and Thompson (1999) and find estimates of the NAIRU of approximately 5-5.25 per cent in early 2014. Lim, Dixon and Tsiaplias (2009) similarly estimate a time-varying equilibrium unemployment rate of 5 per cent in 2008. More recently, the RBA (2016a) has also stated that spare capacity exists in the economy, with the unemployment rate around 0.5 per cent above full employment.

5. Higher housing costs and longer commuting times have been suggested as a factor contributing to Victoria's population growth outstripping New South Wales (Kent 2016b).

6. For an overview of the factors influencing Australian house prices since 1970, see Stapledon (2016).

7. Another source of exposure is developer finance (see RBA 2016c). 